\title{
Асоціативне поле концепту «інформаційна безпека» у дискурсі медіа-психологічної освіти студентів-журналістів
}

\author{
Росінська О. А.
}

Інститут журналістики Київського університету ім. Б. Грінченка

у статті представлено результати дослідження асоціативного поля концепту «інформаційна безпека». Теоретикометодологічною основою роботи стали новітні підходи до інформаційної безпеки як складової психологічної та інформаційної захищеності суспільства. Метою дослідження $є$ виявлення асоціативного поля концепту «інформаційна безпека» за даними асоціативного експерименту з бакалаврами освітніх програм «Журналістика», «Міжнародна журналістика», «Реклама та зв'язки з громадськістю», «Видавнича справа та редагування», діяльність яких безпосередньо пов'язана з інформаційною сферою.

Аналіз концепту «інформаційна безпека» як такого, що формується у свідомості споживача інформації через певне усвідомлення інформаційної та особистісної захищеності в площині соціальних комунікацій у мережі Інтернет, а також такого, що презентує мовну картину світу індивіда в інформаційну епоху, здійснювався на міждисциплінарному рівні.

Зокрема, у дослідженні подано аналіз асоціативного поля концепту «інформаційна безпека» відповідно до отриманих логічних і граматичних реакцій ста вісімнадцяти респондентів. Аналіз за логічним компонентом виявив сім тематичних груп асоціацій: сфера захисту особистої інформації; сфера засобів масової інформації / соціальних мереж; сфера технологій; сфера державної інформаційної безпеки; соціальна сфера; психологічна захищеність; сфера захисту авторської інформації.

Важливість поняття «інформаційна безпека» для цілої низки сфер інформаційної діяльності зумовлюється подальшим розвитком інформаційних технологій та технічних засобів обробки та захисту інформації, тому незаперечною $\epsilon$ перспектива подальшого дослідження поняття в контексті виявлення рівня усвідомлення інформаційної безпеки як підгрунтя інформаційного та особистісного комфорту, а також для вивчення специфіки кореляції асоціативних полів концептів «інформаційна безпека», «інформаційна культура», «інформаційний комфорт», «інформаційний дискомфорт» тощо.

Ключові слова: асоціативне поле; інформація, інформаційна безпека; інформаційне суспільство.

\section{1. Вступ}

Постановка проблеми. Інформація є основним стратегічним ресурсом нового інформаційного суспільства, при цьому інформаційні процеси послідовно впливають на всі сфери його життя. Це актуалізує питання соціального, психологічного комфорту особистості в інформаційному середовищі та зумовлює важливість вивчення ціннісної ваги поняття інформаційної безпеки у свідомості споживачів інформації, які нею постійно оперують - збирають, накопичують і використовують.

На сьогодні інформація не є абстрактним поняттям, оскільки становить цінність на рівні політичному, економічному, репутаційному, особистісному. Крім того, оновлюються форми і процеси ії виробництва, збереження, підвищуються ризики втрати, недобросовісного придбання, володіння, використання із недобрими намірами тощо. Усвідомлення цінності інформації зумовлює необхідність вивчення інформаційної безпеки як порівняно нової, проте надзвичайно прогресивної галузі інформаційних, комунікаційних технологій та соціальних комунікацій у цілому, а також аналізу й корегування їі понятійного апарату.

Ми пропонуємо розглядати поняття «інформаційної безпеки» не тільки у розумінні захищеності інформації й усієї інформаційної інфраструктури від випадкових і навмисних впливів природного чи штучного характеру, що завдають неприйнятної шкоди суб'єктам інформаційних відносин, тобто користувачам і власникам інформації. Вивчення поняття важливе, зокрема, у контексті медіапсихологічної безпеки, оскільки ми усвідомлюємо, що об'єктами такого небажаного інформаційного впливу можуть бути як інформаційнотехнічні системи, так і масова чи індивідуальна свідомість, психіка людини. Тож інформаційну безпеку варто досліджувати також у контексті досягнень таких галузей наукових знань, як медіапсихологія і теорія масових комунікацій, особливо враховуючи те, що сучасний 
інформаційний простір вийшов далеко за межі мас-медіа чи засобів масової інформації, охопивши сферу міжособистісного спілкування. Таким чином, практично кожен користувач у соціальних мережах може отримати трибуну для транслювання власних поглядів, а також вільно оперувати особистими даними інших людей, отримавши через володіння інформацією над ними владу й можливість чинити психологічний тиск.

Аналіз останніх досліджень. Аналіз досліджень із питань інформаційної безпеки як соціально-психологічної категорії доводить, що тільки в деяких із них актуалізовано соціальний аспект проблеми, забезпечення захищеності особистості через захист її особистої інформації, цілісності та особистісної свободи, зокрема у статті А.М. Пелещишина, Р.О.Коржа, У.Б.Ярки «Захист інформаційного образу ВНЗ від цілеспрямованих дій у соціальних середовищах Інтернету» [1], дослідженні Р.І.Проданюк «Інформаційна безпека в соціологічному контексті: до постановки проблеми» [2]. Особливо відчувається брак ґрунтовних досліджень у галузі соціальних комунікацій та психології спілкування (А. І. Гізун [3], А. О. Лісневська [4]), натомість багато уваги приділено правовим аспектам проблеми (В. Д. Гавловський [5]), технічним засобам захисту тощо.

Одним із ключових досліджень у сенсі розуміння зв' язку інформаційної безпеки та психологічної захищеності споживачів інформації є публікація А. Аппарі та М. Джонсона «Інформаційна безпека та конфіденційність у сфері охорони здоров'я: сучасний стан досліджень», опублікована в 2007 р. [6]. Більше уваги приділяється дослідниками вивченню специфіки усвідомлення інформаційної безпеки в соціальних мережах, зокрема можна назвати роботи А. А. Хасіба «Загрози соціальних інтернет-мереж» [7], Дж. Сарідакіса, У.Бенсона, Дж. Езінгерда «Індивідуальна інформаційна безпека, поведінка користувачів та кібервіктимізація: емпіричне дослідження користувачів соціальних мереж» [8], Дж. Нагі, П. Пехо «Безпека соціальних мереж» [9].

Для цього напрямку дослідження інтерес становить публікація В. О. Хорошко, Ю. Є. Хохлачової «Інформаційна війна. ЗМІ як інструмент інформаційного впливу на суспільство» [10], оскільки в ній приділено увагу актуальним для теорії 3МІ та медіапсихології аспектам вивчення поняття «інформаційна безпека» у сфері соціальних комунікацій. Питання інформаційної безпеки держави та окремого споживача інформації в умовах інформаційної війни проаналізовано в роботі А. О. Яфонкіна, В.А. Шевчука «Інформаційна війна проти держави та інформаційна безпека України» [11]. Дотичні за проблематикою також дослідження В.А. Лужецького, А. В. Дудатьєва [12], С. О. Гнатюка та Т. О. Жмурко [13], О. В. Чернадчук [14], 3. М. Бржевської [15], Є. М. Мануйлова, Ю. Ю. Калиновського [16].

У вітчизняній науці варто виділити дослідження Ю. Є. Муравської щодо інформаційної безпеки суспільства у сфері захисту даних при промисловому шпіонажі [17], розвідку Н. С. Грабар «Інформаційна безпека в умовах становлення глобального інформаційного суспільства» [18], В.Г. Кононович,
І. В. Кононович «Визначення ідентичності об'єктів у системі соціальної та інформаційної безпеки» [19]; В. М. Фурашева «Кіберпростір та інформаційний простір, кібербезпека та інформаційна безпека: сутність, визначення, відмінності» [20]. Заслуговує уваги робота О. Л. Гапєєвої «Історіографічний аналіз проблеми інформаційної безпеки на пострадянському просторі», у якій уперше було комплексно проаналізовано дослідження українських та закордонних вчених із питань інформаційної безпеки [21]. Вивчення різних підходів до визначення поняття «інформаційна безпека» зроблено в роботі К. В. Захаренка «Міжнародний досвід інформаційної безпеки» [22].

Варто зауважити, що більшість дослідників вивчають фактори та інструментарій інформаційної безпеки у просторі відкритої інформації в контексті гарантування захисту інформації, натомість на сьогодні потребує дослідження рівень усвідомлення звичайними користувачами поняття інформаційної безпеки, асоціативний зв'язок поняття у свідомості споживача 3 тими чи іншими аспектами функціонування інформаційного простору.

Таким чином, проблема інформаційної безпеки розглядається В площині інформаційних впливів (зокрема, інформаційних війн) як така, що має кібернетичну природу, тому, на нашу думку, важливо дослідження цього явища проводити й у психологічній площині, визначаючи його міждисциплінарну природу.

Метою публікації $\epsilon$ представлення результатів дослідження асоціативного поля концепту «інформаційна безпека» на основі асоціативного експерименту за участю бакалаврів освітніх програм «Журналістика», «Міжнародна журналістика», «Реклама та зв'язки 3 громадськістю», «Видавнича справа та редагування», для яких це поняття безпосередньо пов'язане з професійною діяльністю.

О6'єкт дослідження: асоціативне поле концепту «інформаційна безпека».

Методи дослідження. Вільний асоціативний експеримент проводився у вересні-листопаді 2019 р. зі студентами 1 і 2 курсів, які навчаються за освітніми програмами «Журналістика», «Міжнародна журналістика», «Реклама та зв'язки з громадськістю», «Видавнича справа та редагування».

Метод вільного асоціативного експерименту дозволив уникнути будь-яких обмежень у реакціях респондентів на слово-стимул. Відповіді надсилалися за допомогою Google-форми, що дало можливість залучити максимальну кількість респондентів.

В експерименті взяли участь 118 осіб віком від 17 до 20 (100\%), зокрема чоловіків - 21 (17,9\%), жінок - 97 $(82,2 \%)$. Таким чином, експеримент дає можливість зробити висновки про особливості формування поняття «інформаційної безпеки» у певному віковому та професійному середовищі, однак не створює підстав для визначення гендерних чи вікових відмінностей. При подальшому дослідженні продуктивним може виявитися порівняння вікових показників при залученні осіб 
середнього віку та визначення професійних відмінностей у формуванні поняття.

Учасникам експерименту було запропоновано навести 5 асоціацій на словосполучення-стимул «інформаційна безпека» - важливе поняття фахової сфери у підготовці майбутніх журналістів.

Представлені результати описано з використанням загальнонаукових методів - аналізу, який було використано під час огляду останніх досліджень 3 проблеми, й синтезу для аналізу зібраних результатів та підбиття підсумків здійсненого експерименту, спеціального методу - статистичного аналізу, що застосовувався при описі результатів вільного асоціативного експерименту, визначенні частотності реакцій на поняття-стимул.

\section{2. Результати}

У дослідженні ми виходили з кількох ключових гіпотез сприйняття концепту «інформаційна безпека». Так, Ю. Є. Муравська визначає безпеку як «визначену впевненість біологічних та соціальних істот, яку можна спостерігати через три взаємозалежних виміри, такі як суб'єктивний вимір (як визначеність існування і виживання, що підтверджується відсутністю серйозних загроз для інтересів, які пов'язані з фізичним існуванням), а також об'єктивний і процесуальний вимір (як впевненість у необхідності умов розвитку та активності у цей час і в близькому майбутньому)» [17, с. 290]. Натомість авторка зазначає: «Інформаційну безпеку можемо визначити охороною інформації, яка полягає в ускладненні отримання даних про фізичну природу наявного або планованого стану речей і явищ у їхньому власному просторі функціонування, а також у перешкоджанні внесення змін до інформаційних комунікацій та фізичного знищення носіїв інформації» [17, C. 291].

Н.С. Грабар визначає, що «під інформаційною безпекою розуміють захищеність інформації від незаконного ознайомлення, перетворення і знищення, а також захищеність інформаційних ресурсів від впливів, спрямованих на порушення їх працездатності» [18]. Також дослідниця зазначає: «Основними компонентами інформаційної безпеки $є$ : достовірність і повнота інформації; забезпечення документування історикокультурного процесу; збереження інформації, розглянутої не тільки як збереження матеріальних носіїв культурноісторичної інформації, але і як дбайливе ставлення до емоційно-образної складової культурної спадщини; якість і ефективність культурно-історичної інформації, що визначають провідну роль достовірної культурної спадщини та культурних цінностей в регуляції масової свідомості; забезпечення відповідності об'єктів культурної спадщини i їх атрибуції 3 метою неприпустимості спотворення в комерційних та інших цілях; збереження історико-культурного контексту представляється різними установами науки і освіти інформації і неприпустимість його спотворення в цілях просування ідеології окремих соціальних груп; обмін і співробітництво між установами культури, освіти, 3MІ 3 метою більш повного та достовірного представлення культурно-історичної спадщини» [18].

В. М. Фурашев визначає інформаційну безпеку як «стан захищеності життєво важливих інтересів людини, суспільства і держави, за якого відсутнє завдання шкоди через:

- негативний інформаційний вплив за допомогою, в першу чергу, несанкціонованого створення, розповсюдження, використання свідомо спрямованої за визначеною метою неповної, невчасної, невірогідної та упередженої інформації;

- негативні наслідки застосування інформаційних технологій;

- несанкціоноване порушення режиму доступу до інформації з подальшим іï розповсюдженням та використанням» $[19$, с. 291].

у цілому, узагальнивши всі проаналізовані визначення, можна запропонувати розглядати поняття інформаційної безпеки широко, як систему захисту від інформаційних загроз.

У процесі дослідження асоціативного поля ми можемо послідовно простежувати кореляцію отриманих результатів із тими теоретичними положеннями, на які спиралися.

Вільний асоціативний експеримент дав можливість свободи вибору асоціацій, оскільки не обмежувався інструкцією щодо частиномовної приналежності чи синтаксичної ролі тощо. При цьому відзначено, що концепт-стимул з певною частиномовною приналежністю певною мірою обумовлював частиномовну приналежність реакцій, хоча й не $з$ абсолютним показником.

Було отримано 238 різних асоціацій, не враховуючи повтори.

Говорячи про поняття інформаційної безпеки, більшість дослідників пов'язує його 3 кількома операційними процесами, зокрема: збір, зберігання, обробка, передавання. Асоціативне поле концепту «інформаційна безпека» у нашому дослідженні дає можливість стверджувати, що респондентами усвідомлюється важливість цих процесів, зокрема зафіксовано такі відповіді: зберігання даних - 15, обробка - 8. Також серед асоціацій варто виділити цілу низку таких, що відображають усвідомлення важливості передавання інформації, способів її поширення: медіа, $3 \mathrm{MI}-8$, мережі - 7, доступність інформації - 4, надійні джерела - 2 .

Інформаційна загроза передусім розглядається як небезпечний інформаційний вплив, який може бути різного типу, зокрема втрата цінної інформації, що знижує ефективність інформаційної діяльності або діє на користь опонента чи конкурента.

Більшість респондентів пов'язує інформаційну безпеку саме із захистом інформації: захищеність/захист - 59 відповідей, безпека (захищеність, захист) особистих даних (приватної інформації) - 39 відповідей, конфіденційність - 26 відповідей. Для опитаних віком від 17 до 20 років актуалізується переважно захист 
особистої інформації, натомість вони менше пов'язують інформаційну безпеку 3 державною таємницею, шпіонажем, розвідкою, хоча усвідомлюють необхідність обмеження інформації такого рівня чи цензурування матеріалів: кібербезпека - 9 відповідей, належна інформація, цензура - 9 відповідей; національний інтерес - 1 відповідь, стеження - 1 відповідь.

Інший вид інформаційного впливу пов'язаний із поширенням негативної інформації, що є запланованою маніпуляцією, приводить до помилкових рішень, зумовлених чужими інтересами. Оскільки опитувані вивчають фахові дисципліни спеціальності «Журналістика», то демонструють певний рівень усвідомлення необхідності надання правдивої інформації, перевірки фактів тощо: достовірність - 11 відповідей, правдивість - 7 відповідей, перевірка фактів 7 відповідей, інформація без маніпуляцій / пропаганди 8 відповідей, фільтрування інформації - 5 відповідей, надійні джерела - 2 відповіді.

Н. С. Грабар у своєму дослідженні зазначає, що «однією з особливостей забезпечення інформаційної безпеки в автоматизованій системі $\epsilon$ те, що таким абстрактним поняттям, як інформація, об'єкти і суб'єкти системи, відповідають фізичні уявлення в комп'ютерному середовищі: для подання інформації - машинні носії інформації у вигляді зовнішніх пристроїв комп'ютерних систем, оперативної пам'яті, файлів і т. д.; об'єктам системи - пасивні компоненти системи, що зберігають, які беруть або передають інформацію» [18].

Асоціативне поле концепту «інформаційна безпека» дає можливість переконатися в слушності таких теоретичних висновків, оскільки послідовно визначено низку асоціацій, що пов'язані з:

- машинними носіями інформації: програмування (1); IT-технології (1); інформаційні технології (2); комп' ютер (3);

- пасивними елементами системи: програмне забезпечення (1); вірус/антивірус (11); пароль (7); зберігання даних (15);

- активними компонентами системи: програміст (1).

Також можна додати до класифікації асоціації, що демонструють уявлення про:

- систему в цілому - Інтернет (14); система (1); павутина (1);

- взаємодію систем - кібербезпека/кібератака (9), щит/інформаційний щит (2).

Асоціативне поле концепту «інформаційна безпека» також цілком корелює з іншим твердженням дослідника, що «інформаційна безпека комп'ютерних систем досягається забезпеченням конфіденційності, цілісності та достовірності даних, що обробляються, а також доступності та цілісності інформаційних компонентів і ресурсів системи [18]»: конфіденційність - 26 відповідей, доступність - 12 відповідей / доступність інформації - 4 відповіді, цілісність - 15 відповідей, достовірність - 11 відповідей.

Аналіз за логічним компонентом

Тематичні асоціації становлять істотний відсоток та поділяються на 7 основних груп:
- сфера захисту особистої інформації: захист/захищеність особистих даних / приватної інформації (59); конфіденційність (26), безпека (9); безпека у соціальних мережах (4); приватність (3); безпечні ресурси (3); особистий простір (3); недоторканість (3); таємниця (1); безпека приватного спілкування (1); обережність (1); обізнаність (1); безпека приватного спілкування (1);

- сфера засобів масової інформації/соціальних мереж: конфіденційність (26); достовірність (11); медіа/3МІ (8); інформація без маніпуляцій і пропаганди (5); перевірка достовірності фактів/інформації (7); об'єктивність (7); фейк (3); надійні джерела (2); точність (2); якісні новини (1); фільтрування інформації (1); безпека в Інтернеті (1); бан шкідливих (1); інфополе (1); наявність першоджерел (1); відкритість (1); відповідальність (1); статистика (1); чесність (1); відкритість (1) тощо;

- сфера технологій: Інтернет (14); зберігання даних (15); вірус/антивірус (11); кібербезпека/кібератака (9); пароль (7); щит/інформаційний щит (2); інформаційні технології (2); програміст (1); програмне забезпечення (1); комп'ютер (3); павутина (1); система (1); телефон (1); програмування (1); ITтехнології (1) тощо;

- сфера державної інформаційної безпеки: безпека (9); кібербезпека (9); цензура (9); доступність (12); свобода (7); толерантність (2); запобігання (2); безпека для дітей (1); таємниця (1); пильність (1); відповідальність (2); демократія (1); відсутність популістських заяв (1); відкритість політиків (1); статистика (1); інформаційна війна (1); національний інтерес (1); стеження (1); довіра (1); секретність (1) тощо;

- соціальна сфера: безпека (9); безпека для дітей (1); пенсіонери (1); булінг (1); незалежність (1); демократія (1); неповнолітні громадяни (1) тощо;

- психологічна захищеність: спокій (5); толерантність (2); підтримка (1); відгородженість від проблем (1); критичне мислення (1); здорова інформація (1); довіра (1); обережність (1); булінг (1) тощо.

- сфера захисту авторської інформації: захист авторських прав (2); ліцензія (1); піратство (1) тощо.

Здійснений аналіз дозволяє зробити висновки, що більшість реакцій мають прямий семантичний зв'язок зі словом-стимулом, тобто представляють центральну логічну реакцію (86 \%), периферичні реакції становлять $14 \%$.

Серед виявлених у результаті вільного асоціативного експерименту асоціацій можна виділити блок типових, що традиційно виявляються в ході дослідження асоціативних полів. Такі реакції $€$ первинними, зокрема "захищеність", «захист», «безпека», «конфіденційність», «анонімність». Частотні (типові) реакції визначають основу сприйняття студентами ключового поняття їхньої професійної діяльності - інформаційної сфери.

Частотними реакціями виявилися «захищеність/захист» (59), «безпека» (39), «конфіденційність» (34), «зберігання даних» (15), "доступність/доступність даних" (16), що корелює 3 основними підходами теоретиків до поняття «інформаційна безпека».

Однак дослідники мало приділяли уваги зв'язку інформаційної безпеки з діяльністю ЗМІ як носіїв та 
поширювачів інформації, натомість ця сфера стала досить актуальною для студентів спеціальності «Журналістика» (освітні програми «Журналістика», «Реклама та зв'язки з громадськістю», «Видавнича справа та редагування»).

Серед отриманих до слова-стимулу асоціацій можна виділити такі, що протиставлялися йому, фактично були антонімічними, відображаючи сферу відсутності «інформаційної безпеки»: фейк (3), кібератака (2), стеження (1), маніпуляція (1).

\section{Аналіз за граматичним компонентом}

Асоціативне поле концепту «інформаційна безпека» дає цілу низку парадигматичних зв' язків асоціацій.

За частотністю помітно переважали парадигматичні зв'язки між асоціаціями, тобто такі, що належать до одного граматичного класу: захист, захищеність, безпека, толерантність, доступність, достовірність, правдивість, точність, анонімність, конфіденційність тощо. Це цілком зумовлюється типовими реакціями на слово-стимул, що зазвичай викликає відповідну за частиномовною приналежністю реакцію. Так само типовим $€$ добір до слова-реакції чи слова-стимулу атрибутивного компоненту (поняття + ознака поняття): інформаційний щит, надійні джерела, якісна інформація, однак такі реакції виявилися нечастотними серед відповідей респондентів.

Частотною серед відповідей респондентів виявилася інформаційна захищеність, що являє собою добір відповідного за структурою сполучення слів із заміною основного компоненту словосполучення-стимулу.

\section{3. Обговорення}

Поняття-стимул дало низку цікавих периферійних реакцій, зокрема спокій (1), підтримка (1), чесність (1), пенсіонери (1), неповнолітні громадяни (1), комунікація (1), реклама (1), що проявлені як нечастотні, однак при подальшому вивченні кореляції асоціативних полів концептів «інформаційна безпека», «інформаційна культура», «інформаційний комфорт», «інформаційний дискомфорт», які досліджуються в межах колективної наукової теми, існує можливість віднайдення точок сходження асоціативних полів понять інформаційної сфери.

Таким чином, дослідження асоціативного поля концепту «інформаційна безпека» демонструє специфічні результати, пов'язані зі змістовим наповненням підготовки фахівців зі спеціальності «Журналістика», зокрема усвідомлення ними зв'язку інформаційної безпеки з якістю подання інформації засобами масової інформації, якістю перевірки інформації, надійністю джерел, точністю та коректністю формулювань.

\section{4. Висновок}

Дослідження дає змогу зробити висновок про те, що потрактування поняття «інформаційна безпека» для різних категорій суб'єктів (зокрема, задіяних у різних професійних сферах) може помітно відрізнятися.

Інформаційна безпека не обмежується тільки захистом інформації як такої, що зберігається певними засобами на певних носіях, а пов'язується зі сферою особистісного захисту, психологічного та комунікативного комфорту.

Результати проведеного асоціативного експерименту підтверджують міждисциплінарний характер концепту «інформаційна безпека» та можливість його дослідження в різних теоретичних та прикладних наукових напрямах, зокрема психолінгвістичному (вивчення мовного поля концепту), медіапсихологічному (усвідомлення інформаційного комфорту споживачем інформації), комунікативному (інформаційна безпека як гарантія) тощо.

Асоціативне поле поняття «інформаційна безпека» дає можливість виділити різні тематичні групи, зокрема: сфера захисту особистої інформації; сфера засобів масової інформації / соціальних мереж; сфера технологій; сфера державної інформаційної безпеки; соціальна сфера; психологічна захищеність; сфера захисту авторської інформації.

Аналіз за граматичним компонентом засвідчує, що за частотністю помітно переважали парадигматичні зв'язки між асоціаціями, тобто такі, що належать до одного граматичного класу: захист, захищеність, безпека, толерантність, доступність, достовірність, правдивість, точність, анонімність, конфіденційність тощо. Це зумовлюється типовими реакціями на слово-стимул, що зазвичай викликає відповідну за частиномовною приналежністю реакцію. Так само типовим є добір до слова-реакції чи слова-стимулу атрибутивного компонента (поняття + ознака поняття): інформаційний щит, надійні джерела, якісна інформація, однак такі реакції виявилися нечастотними серед відповідей респондентів.

Частотною серед відповідей респондентів виявилася інформаційна захищеність, що являє собою добір відповідного за структурою сполучення слів із заміною основного компоненту словосполучення-стимулу.

Оскільки поняття «інформаційна безпека» $\epsilon$ актуальним для медіапсихологічних досліджень та досліджень у галузі соціальних комунікацій, перспективним $€$ продовження його вивчення, зокрема в кореляції 3 поняттями «інформаційна культура», «інформаційний комфорт», «інформаційний дискомфорт» тощо.

\section{Список бібліографічних посилань}

1. Пелещишин А.М., Корж Р.О., Ярка У.Б. Захист інформаційного образу ВНЗ від цілеспрямованих дій у соціальних середовищах інтернету. Захист інформації. 2012. № 3. C. 87-93.

2. Prodaniuk R.I. Information ecological as a key condition for information security: the sociological aspect. Grani. 2018. Vol. 21. No. 8. doi: 10.15421/1718998.

3. Гізун А., Гріга В. Аналіз сучасних теорій інформаційнопсихологічних впливів в аспекті інформаційного протиборства. Безпека інформації. 2016. Т. 22. № 3. С. 272282. doi: $10.18372 / 2225-5036.22 .11102$.

4. Лісневська А.О. Психологічна безпека студентської молоді в контексті сприймання новин із засобів масової інформації. Вісник ХДУ. Серія: Психологічні науки. 2019. № 1. C. 245-251. doi: 10.32999/ksu2312-3206/2019-1-41.

5. Цимбалюк В.С. Основи інформаційного права України: навч. посіб. Київ : Знання, 2004. 274 с. 
6. Appari A., Johnson M. Eric. Information security and privacy in healthcare: current state of research. Internet and Enterprise Management. 2010. Vol. 6. No. 4. P. 279-282.

7. Abdullah A.H. Threats of Online Social Networks. IJCSNS International Journal of Computer Science and Network Security. 2009. Vol. 9. No. 11. P. 288-293.

8. Saridakis G., Benson V., Ezingeard J.N. Individual information security, user behaviour and cyber victimisation: An empirical study of social networking users. Technological Forecasting and Social Change. 2016. Vol. 102. P. 320-330.

9. Nagy J., Pecho P. Social Networks Security. Third International Conference on Emerging Security Information, Systems and Technologies. 2009. doi: 10.1109/ SECURWARE.2009.56.

10. Хорошко В., Хохлачова Ю. Інформаційна війна. ЗМІ як інструмент інформаційного впливу на суспільство. Частина 1. Безпека інформації. 2016. Т. 22. № 3. С. 283-288. doi: 10.18372/2225-5036.22.11104.

11. Яфонкін А.О., Шевчук В.А. Інформаційна війна проти держави та інформаційна безпека України. Forum Prava. 2017. № 5. C. 466-472. doi: 10.5281/zenodo.1206228.

12. Лужецький В.А., Дудатьєв А.В. Концептуальна модель системи інформаційного вплив. Безпека інформації. Ukranian Scientific Juornal of Information Security. T. 23. № 1. 2017. doi: 10.18372/2225-5036.22.11099.

13. Gnatyuk S., Zhmurko T. Information-Psychological Security of Society in the Context of Information Warfare. Inżynier XXI wieku projectujemy przyszlosc. Bielsko-Biała: Wydawnictwo Naukowe Akademii Techniczno-Humanistyczne w Bielsku-Białej, 2016. P. 321-341.

14. Чернадчук О.В. Забезпечення інформаційної безпеки: виклики сьогодення. Правові горизонти. 2018. Вип. 13 (26). C. 79-85. doi: 10.21272/legalhorizons.2018.i13.p79.

15. Бржевська 3.М, Довженко Н.М., Киричок Р.В., Гайдур Г.І., Аносов А.О. Інформаційні війни: проблеми, загрози та протидія. Кібербезпека: освіта, наука, техніка. 2019 T. 3. № 3. С. 88-94. doi: 10.28925/2663-4023.2019.3.8896.

16. Мануйлов Є.М., Калиновський Ю.Ю. Інформаційний суверенітет України: сучасні виклики та загрози духовній сфері. Вісник національного юридичного університету ім. Я.Мудрого. Серія: філософія, філософрія права, політологія, сочіологія. 2019. Т. 3. № 42. С. 22-34. doi: 10.21564/2075 7190.42 .170288 .

17. Муравська Ю.Є. Інформаційна безпека суспільства: концептуальний аналіз. Економіка і суспільство. 2017. № 9. C. 289-294.

18. Грабар Н.С. Інформаційна безпека в умовах становлення глобального інформаційного суспільства. Державне управління: удосконалення та розвиток. 2019. № 7. doi: 10.32702/2307-2156-2019.7.21.

19. Кононович В.Г. Визначення ідентичності об'єктів у системі соціальної та інформаційної безпеки. Сучасний захист інформації. № 1. 2015. С. 19-27.

20. Фурашев В.М. Кіберпростір та інформаційний простір, кібербезпека та інформаційна безпека: сутність, визначення, відмінності. Інформація і право. 2012. № 2(5). C. $162-175$.

21. Гапеєва О.Л. Історіографічний аналіз проблеми інформаційної безпеки на пострадянському просторі. Historical and Cultural Studies. 2016. Vol. 3. No. 1. P. 37-41.

22. Захаренко К.В. Міжнародний досвід інформаційної безпеки. Сучасне суспільство. 2019. № 1 (17). С. 95-109. doi: 10.34142/24130060.2019.17.1.09.

\section{References}

1. Peleshchyshyn, A.M., Korzh, R.O., \& Yarka U.B. (2012) "Protecting the information form of the university from purposeful in all modern Internet", Western information, 3, pp. 87-93.

2. Prodaniuk, R.I. (2018) "Information ecological as a key condition for information security: the sociological aspect", Grani, 21(8). doi: 10.15421/1718998.

3. Gizun, A. \& Griga, V. (2016) "Analysis of modern theories of information and psychological influences in the aspect of information confrontation", Information security, 22(3), pp. 272-282. doi: 10.18372/2225-5036.22.11102.

4. Lisnevska, A.O. (2019) "Psychological safety of student youth in the context of news media perception", Scientific Bulletin of Kherson State University. Series: Psychological Sciences, (1), pp. 245-251. doi: 10.32999/ksu2312-3206/2019-141.

5. Cymbalyuk, B.C. (2004) Fundamentals of Information Law of Ukraine. Kyiv: Znannya.

6. Appari, A. \& Johnson, M. E. (2010) "Information security and privacy in healthcare: current state of research", Internet and Enterprise Management, 6(4), pp. 279-282.

7. Abdullah, A. H. (2009) "Threats of Online Social Networks", IJCSNS International Journal of Computer Science and Network Security, 9(11), pp. 288-293.

8. Saridakis, G., Benson, V. \& Ezingeard, J.N. (2016) "Individual information security, user behaviour and cyber victimisation: An empirical study of social networking users", Technological Forecasting and Social Change, 102, pp. 320-330.

9. Nagy, J. \& Pecho, P. (2009) "Social Networks Security", Third International Conference on Emerging Security Information, Systems and Tech nologies, pp.321-325. doi: 10.1109/SECURWARE.2009.56.

10. Khoroshko V. \& Khokhlacheva Yu. (2016) "The information war. Media as a tool for informational influence on society. Part 1". Information security, 22(3), pp. 283-288. doi: 10.18372/2225-5036.22.11104.

11. Yafonkin, A.O. \& Shevchuk, V.A. (2017) "Information war against the state and information security of Ukraine", The forum of the truth, 5, pp. 466-472. doi: 10.5281/zenodo.1206228.

12. Luzheczkyj, V.A., Dudatyev, A.V. (2017) "Conceptual model of information impact system", Information security. Ukranian Scientific Juornal of Information Security, 23(1). doi: 10.18372/2225-5036.22.11099.

13. Gnatyuk, S. \& Zhmurko, T. (2016) "InformationPsychological Security of Society in the Context of Information Warfare", in: Rysiński J. (ed.) 21st century engineer, designing the future, monograph. Bielsko-Biała: Scientific Publishing House of the University of Technology and Humanities in Bielsko-Biała, pp. 321-341.

14. Chernadchuk, O.V. (2018) "Information security: the challenges of today", Legal horizons, 13(26), pp. 79-85. doi: 10.21272/legalhorizons.2018.i13.p79.

15. Brzhevska, Z. et al. (2019) "Information wars: problems, threats and counteraction", Cybersecurity: education, science, technology, 3(3), pp. 89-94. doi: 10.28925/26634023.2019.3.8896.

16. Manujlov, Y. \& Kalynovskyj, Y. (2019) “Information sovereignty of Ukraine: current challenges and threats to the spiritual realm", Bulletin of the National Law University Ya. Mudrogo. Series: Philosophy, Philosophy of Law, Political Science, Sociology, 3(42), pp. 22-34. doi: 10.21564/20757190.42.170288. 
17. Muravska, Y. (2017) "Information security of society: conceptual analysis", Economy and society, 9, pp. 289-294.

18. Grabar, N.S. (2019) "Information security in the conditions of formation of the global information society", Public administration: improvement and development, 7. doi: 10.32702/2307-2156-2019.7.21

19. Kononovych, V.G. (2015) "Identifying the Identity of Objects in Social and Information Security", Modern protection of information, 1, pp. 19-27.
20. Furashev, V.M. (2012), "Cyberspace and information space, cybersecurity and information security: essence, definitions, differences", Information and law, 2(5), pp. 162175.

21. Gapeyeva, O.L. (2016), "Historiographical analysis of the problem of information security in the post-Soviet space", Historical and Cultural Studies, 3(1), pp. 37-41.

22. Zaxarenko, K.V. (2019), "International experience in information security", Modern society, 1 (17), pp. 95-109. doi: 10.34142/24130060.2019.17.1.09.

\section{Rosinska 0 . The associative field of the concept of "information security" in the discourse of media- psychological education of the journalism students}

The article presents the results of research of the associative background of the 'information security' concept.

New approaches to information security as a component of psychological and information safety of the society have become a theoretic and methodic basis of the work. The purpose of the research is to find out the associative background of the 'information security' concept under the results received from the associative experiment with bachelors of 'Journalism', 'International Journalism', 'Advertising and Public relations', 'Publishing and Editing' educational programs, the activity of which is directly related to information area. The 'information security' concept was analyzed at inter-disciplinary level as the one that is formed in the mind of the consumer of the information through particular comprehension of information and personal security through the lens of social communications on the Internet, as well as the one that represents a language picture of the world of an individual in the age of information. Particularly, the analysis of the associative background of the 'information security' concept is presented in compliance with the logical and grammar responses received from one hundred and eighteen respondents. The analysis by logical components showed seven theme groups of associations - the area of personal information protection; the area of mass media/social networks; the area of technologies; the area of state information security; social area; psychological safety; the area of author's information protection. It has been established the interconnection between the results received and the provisions of the researches of Yu.Ye. Muravska, N.S. Hrabar, V.H. Kononovych, I.V. Kononovych, V.M. Furashev. The importance of the 'information security' concept for a whole range of information activity areas, the development of information technologies and technical means for processing and protection information create great perspectives for further research of the concept in the context of finding the comprehension level of information safety as a basis of information and personal comfort, as well as to study specific nature of the correlation of associative backgrounds of the concepts of 'information safety', 'information comfort', 'information discomfort', etc.

Key words: associative centre, information, information security, information society. 